\title{
Technology, Trade and 'Urban Poor' in a General Equilibrium Model with Segmented Domestic Factor Markets
}

\author{
Soumyatanu Mukherjee \\ Indian Institute of Management Kozhikode, CREDIT \& GEP, University of Nottingham \\ (U.K.)
}

Email: smukherjee@iimk.ac.in; soumyatanu16@gmail.com

\begin{abstract}
:
Motivated by a set of stylised facts based on the provincial data for India, this paper, by utilising a four-sector general equilibrium framework with segmented labour and capital markets (domestic), proposes that factor-specific technological progress only in the capital-intensive segment of the urban formal sectors may affect the urban informal workers adversely, while a technological progress (tradeinduced) in the vertically integrated skill-intensive formal sector benefits them. The quantitative analysis demonstrates that when both of the formal sectors undergo capital-using technological progress, urban informal wage may improve, provided the vertically integrated formal sector could save more on the capital cost of production compared to the relatively capital-intensive formal sector and capital flows to the informal sectors. This helps understand trends in urban poverty given the strong association between urban informal wage and the degree of urban poverty.
\end{abstract}

Keywords: Technological Progress; Urban Informal Wage; General Equilibrium.

JEL Classifications: E26; F11; F16; J46; I32; O17. 


\title{
Technology, Trade and 'Urban Poor' in a General Equilibrium Model with Segmented Domestic Factor Markets
}

\begin{abstract}
:
Motivated by a set of stylised facts based on the provincial data for India, this paper, by utilising a four-sector general equilibrium framework with segmented labour and capital markets (domestic), proposes that factor-specific technological progress only in the capital-intensive segment of the urban formal sectors may affect the urban informal workers adversely, while a technological progress (tradeinduced) in the vertically integrated skill-intensive formal sector benefits them. The quantitative analysis demonstrates that when both of the formal sectors undergo capital-using technological progress, urban informal wage may improve, provided the vertically integrated formal sector could save more on the capital cost of production compared to the relatively capital-intensive formal sector and capital flows to the informal sectors. This helps understand trends in urban poverty given the strong association between urban informal wage and the degree of urban poverty.
\end{abstract}

Keywords: Technological Progress; Urban Informal Wage; General Equilibrium.

JEL Classifications: E26; F11; F16; J46; I32; O17. 


\section{Introduction}

It is well-known that in a developing economy the 'informal sector' hosts a substantial proportion of the workforce in unregistered activities, as the less regulated part of the economy where minimum wage laws and labour regulations are either totally absent or weakly implemented. Such sectors are mainly engaged in producing non-traded items in the economy. These sectors primarily comprise own-account enterprises, and also many subcontract firms (producing various parts and semi-processed components for the formal sector firms). As suggested by many authors (Agenor, 1996; Schneider and Enste, 2000 and the references therein) more than $70 \%$ of the workforce is engaged in the informal sector of a developing country (hereafter DC). In South Asian countries such as India, a significant proportion (about 85\% in non-agricultural activities of India) of the working population are engaged in the informal sector. On 2010-11, the informal sector accounted for almost 94 per cent of India's workforce (National Sample Survey (NSS) Report No. 549, 2010-11). Such sectors comprise mainly "wage hunters and gatherers" (Breman 1994), who are usually but not always uneducated, with little or no chance of a living wage and can hardly afford to remain unemployed.

One important implication of the 1991 economic reform in India has primarily been the productivity improvement, primarily capital-using (i.e. labour-saving) in nature, in the organised (formal) manufacturing and service sectors of the urban area; as evidenced in Pattnayak and Thangavelu (2005), Hulten and Srinivasan (1999) and so on. In light of the evidences provided in Hasan (2002), Golder and Kumari (2003), Topalova and Khandelwal (2011) and so on; such productivity surge in the Indian skill-intensive manufacturing or services industries during the liberalised regime has particularly been driven by greater access to the newer varieties of imported inputs from abroad, owing to the lowering of input tariffs. However, following such a technological change in the urban formal sectors, organisation of production between the organised and unorganised (informal) segments of the urban economy should be affected; which would, in turn, impart informal activities, wages and employment. Therefore, benefits of productivity improvement in the formal sectors should have percolated to the bottom of the income group working in the urban informal sectors. While it is difficult to assess such an impact at the micro level and in terms of various indicators of poverty and human development, by exploring the general equilibrium impact 
of productivity take-offs in the formal manufacturing sectors on the informal wage and employment, this paper, according to the definition of income poverty (people are poor if they earn abysmally low wages, which is common among the informal sector workers in developing countries like India), serves to draw an inference on the well-being of the 'poor' urban workers working in the informal sectors. This works in the present context because these workers do not have to be necessarily unemployed in order to be considered poor; prevalence of very low market determined wages describes the impoverishment of those people, who are engaged in informal activities. Vertical production linkages within the domestic urban economy as well as international outsourcing (fragmentation) of production in the formal (skill-intensive) sector have been incorporated within an encompassing general equilibrium model (of production and trade) for the urban economy of a developing country like India; while regarding the factor markets, the model not only allows for having formalinformal segmentation in domestic labour markets, but also for having imperfection in the informal sector capital (credit) market to execute this crucial issue.

\subsection{Some Stylised Facts}

India experienced productivity surge in the organised urban manufacturing (formal) sectors (covered under the Annual Survey of Industries (ASI) act) over the ten-year period from 2000 to 2010 in almost all the provinces. ${ }^{1}$

\footnotetext{
${ }^{1}$ The survey data on the registered manufacturing industries across 27 major Indian states available from the Annual Survey of Industries (ASI) have been used to compute total factor productivity growth (TFPG) using the growth accounting method for the survey years 2000-01, 2005-06 and 2010-11. Details on the construction of TFPG is available in Appendix II.
} 


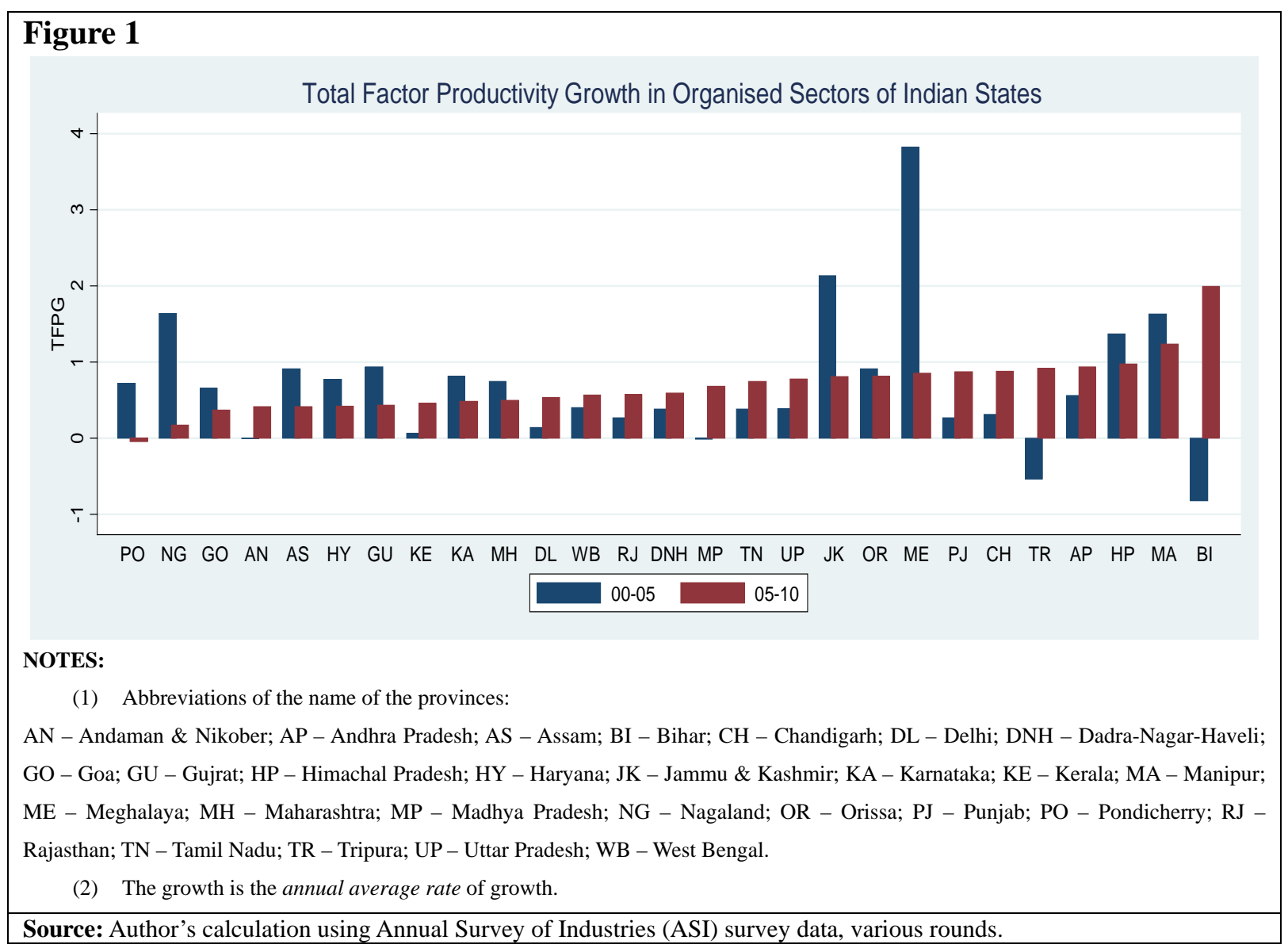

Furthermore, labour productivity in the organised formal sectors has increased fairly evenly across the provinces of India between 1989 and 2010 as revealed in Figure 2 below:

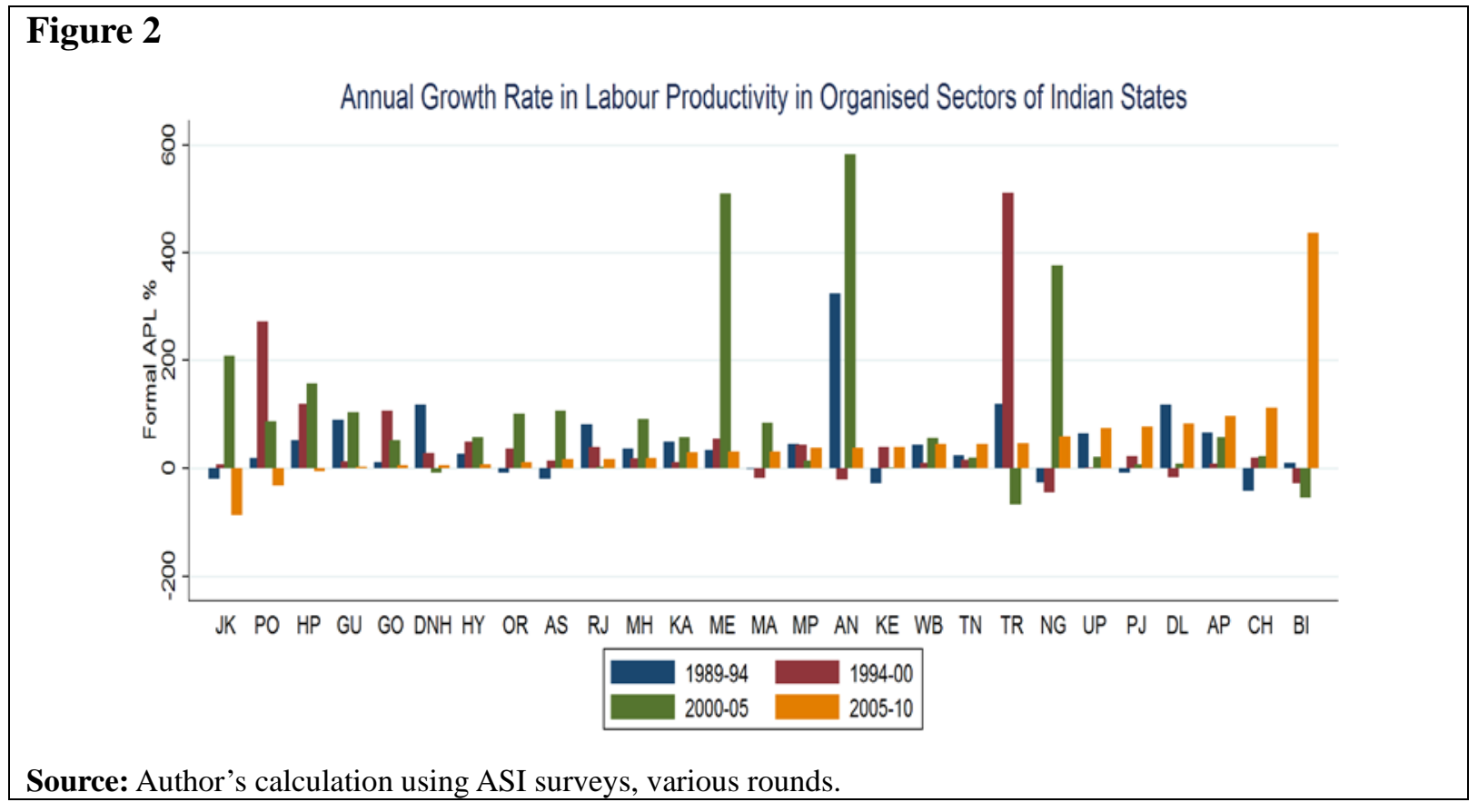


However, we observe a sharp increase in real informal wages in the urban areas during this period as observed in the following figure. To construct the variables for urban unorganised informal sector in the context of the sample under consideration, data from various rounds of surveys conducted by ‘National Sample Survey Organisation’ (NSSO) of the Government of India for Non-Directory Manufacturing Establishments (NDMEs) (not covered under the ASI act and having strong inter-linkages with the organised sectors) in the urban areas have been utilised in this paper. This paper utilises NSS surveys for 1989-90, 1994-95, 2000-01, 200506 and 2010-11 across twenty-seven Indian provinces for this purpose. Detailed construction of variables (including that of the real informal wage) from survey data are available in Appendices II and III.

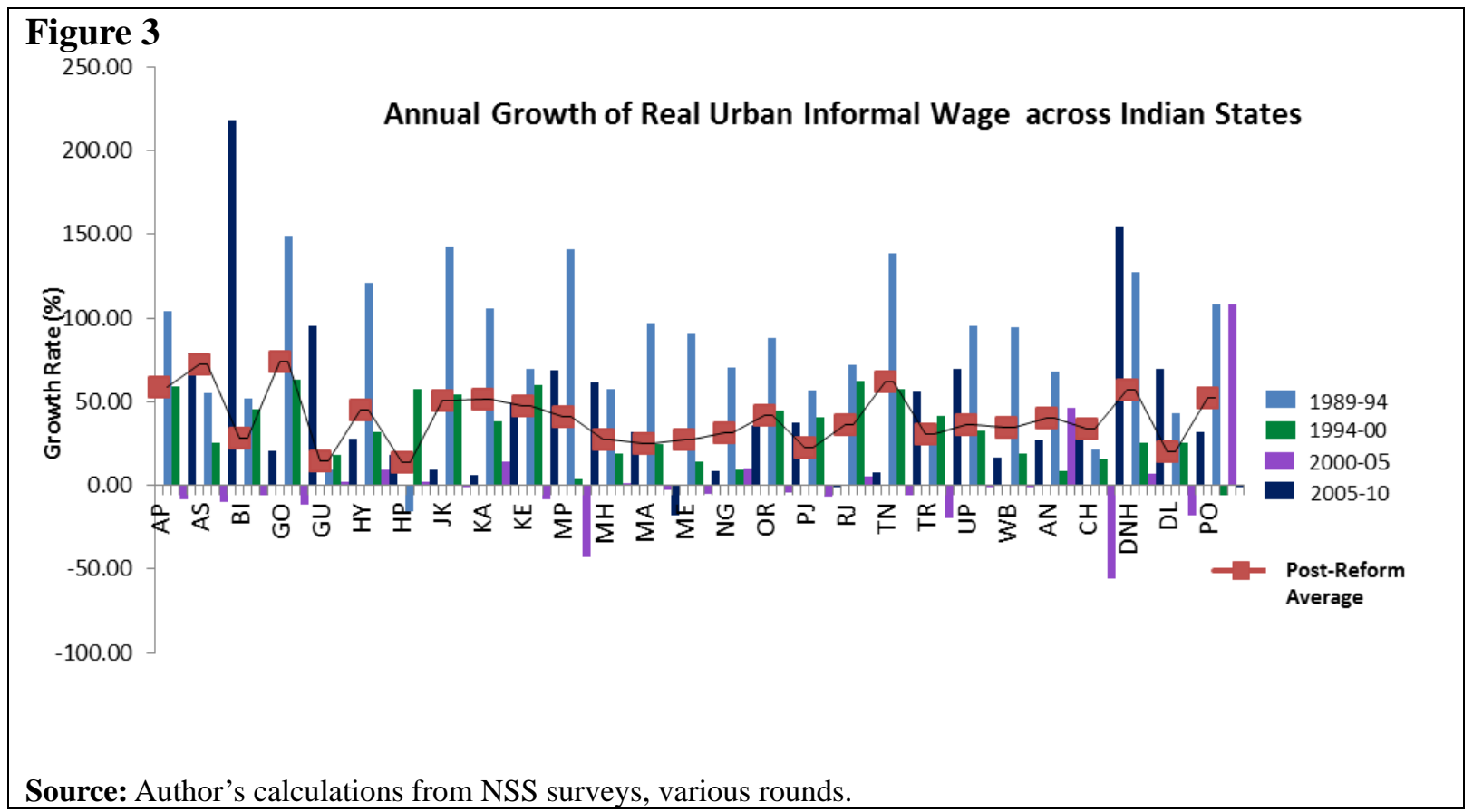

This seems a puzzle since we observe improvement in labour productivity in the formal sectors and increase in informal wages concurrently during the liberalised regime in Indian provinces.

However, Sundaram et al. (2012) found strong positive correlation between formal and unorganised (informal) sector activities (employment, output and value added) at the industry-province level, which supports significantly the inter-linkage between formal and 
informal sectors. Also the reliance of formal sectors on informal sectors is much higher where labour laws are more stringent and organised sectors are relatively human capital (or skill) intensive (Sundaram et al. 2012). This is because the formal sector firms with rigid labour markets and higher skill-requirement often find it profitable to farm out a part or whole of their production to the informal sector firms (that enjoy advantages of cheap labour supply) to avoid various regulations and associated costs. On the other hand, the informal firms are also dependent on formal firms for marketing their products and, in particular, for the supply of credit from the formal sector firms since the formal firms usually have an advantage over the informal firms in the credit market.

In this context, this paper constructs a broad measure of input purchases by the formal sectors from local informal firms. This variable, capturing the notion of vertical production linkages between urban formal and informal sectors, is the sum of

(a) Value of products sold by the registered factories in the same condition as purchased from the other local firms; and

(b) Cost of contract and commission work done by others on materials supplied by the factory.

(c) Total delivered value of all other materials (other than fuel), which have not been produced by the registered factories.

The first two items together constitute a measure of subcontracting. ${ }^{2}$

However, value added has been rising over time in both the informal and formal manufacturing sectors. On the other hand, employment in the formal sector has remained static or has even been slightly declining, while in the informal sector it has been rising steadily. Therefore, in case of value added, a percent-to-percent match in the growth of formal and informal manufacturing has been obtained, which is indicative of some degree of complementarity between the two sectors, while the growth in population or labour force has mainly been absorbed by the informal manufacturing sector. The positive growth rate in

\footnotetext{
${ }^{2}$ Ramaswami (1999) measured subcontracting intensity in formal sectors in a similar fashion. He used the ratio of the value of goods sold in the same condition as purchased to value-added as a measure, but this excludes other forms of subcontracting recorded as contract work performed on materials supplied.
} 
subcontracting activity during the liberalised regime in most of the Indian provinces can be observed in Figure $4 .^{3}$

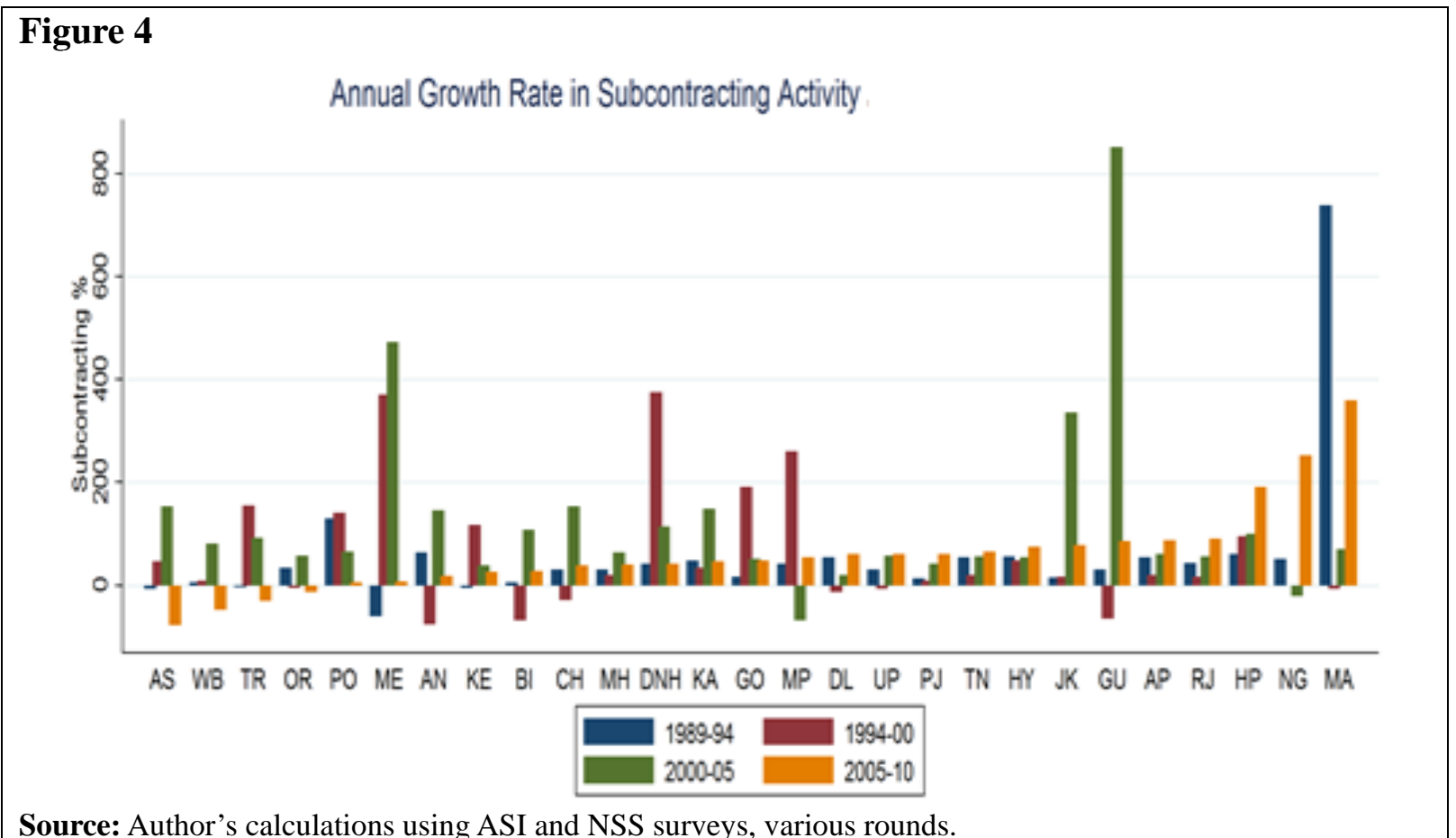

A high rate of growth is also observed in accumulation of real fixed assets of urban NDMEs (relative to that in the registered factories), an approximation to capital accumulation in the urban informal sectors relative to that in formal sectors, ${ }^{4}$ across almost all the 27 provinces (Figure 5) during the liberalised regime.

\footnotetext{
${ }^{3}$ Although for some of the provinces, for some particular year-interval(s), we observe negative annual growth rate in subcontracting activity, such as for Assam during 2005-10. This means that the growth rate of the variable comprising total value of products sold by the registered factories in the same condition as purchased from the other local firms, together with the costs of contract and commission work done by others on materials supplied by the factory, declined from 2005 to 2010 for Assam. This, in turn, implies over this time period, registered factories of Assam have lesser reliance on local resources for their production.

${ }^{4}$ Other more appropriate variable, such as 'Working Capital' in the urban NDMEs to provide a proper notion of 'Capital' could not be utilised, due to data-unavailability. However, the overwhelming fixed assets formation in the informal sectors definitely indicates that a large portion of the investments (previously in the formal sector) has flown into the informal segment. Kar and Marjit (2009) have also used this empirical approximation. For some provinces, however, we observe negative annual growth rate of relative capital accumulation for some particular time-interval. That means, over this particular time-interval, lesser capital has been reallocated to the informal sectors from the formal sectors in these provinces.
} 


\section{Figure 5}

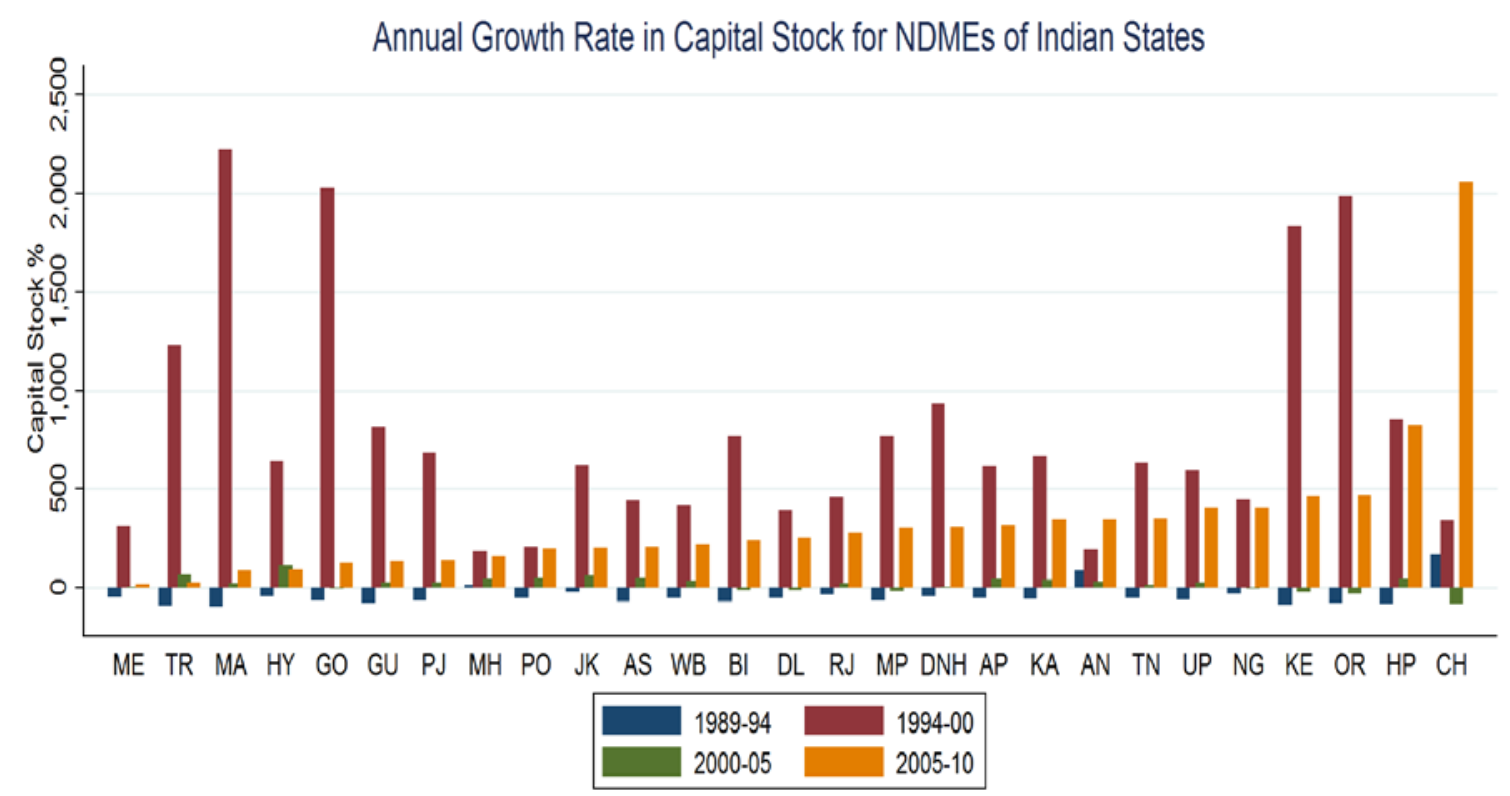

Source: Author's calculations using NSS surveys, various rounds.

Therefore, we observe four concurrent events across Indian provinces during the liberalised regime: productivity improvement in the organised sectors, formal-informal production linkages in the urban area, movement of both capital and labour to the informal sectors, and sharp increase in informal wages. Hence, it becomes a challenge to the trade-theorist to explore channel(s) through which technological progress in the organised sectors can plausibly lead to increase in urban informal wage and subsequently impart employment in the urban informal sectors for a small, open developing economy like India - that typically suffers from rigid organised sector labour market and imperfection in credit market of the informal sector.

Against this backdrop, this paper explores the association between the urban informal wage and urban poverty at the provincial level to motivate the main research agenda, calculating the poverty head count ratios in the urban areas of Indian provinces for the years 2004-05 and 2011-12. As demonstrated in Figure 6 (below), the head count ratio has dropped across all the provinces except Nagaland. The increase in the urban informal wage between 2005 and 2010 (as shown in Figure 3) in these Indian states can plausibly be one significant reason for the decrease in urban poverty headcount ratio, given the fact that the majority of the urban poor in India are engaged in the non-agricultural urban informal sector. This observation 
substantiates the choice of informal wage as a reasonable benchmark to conclude on the welfare implications of 'urban poor'.

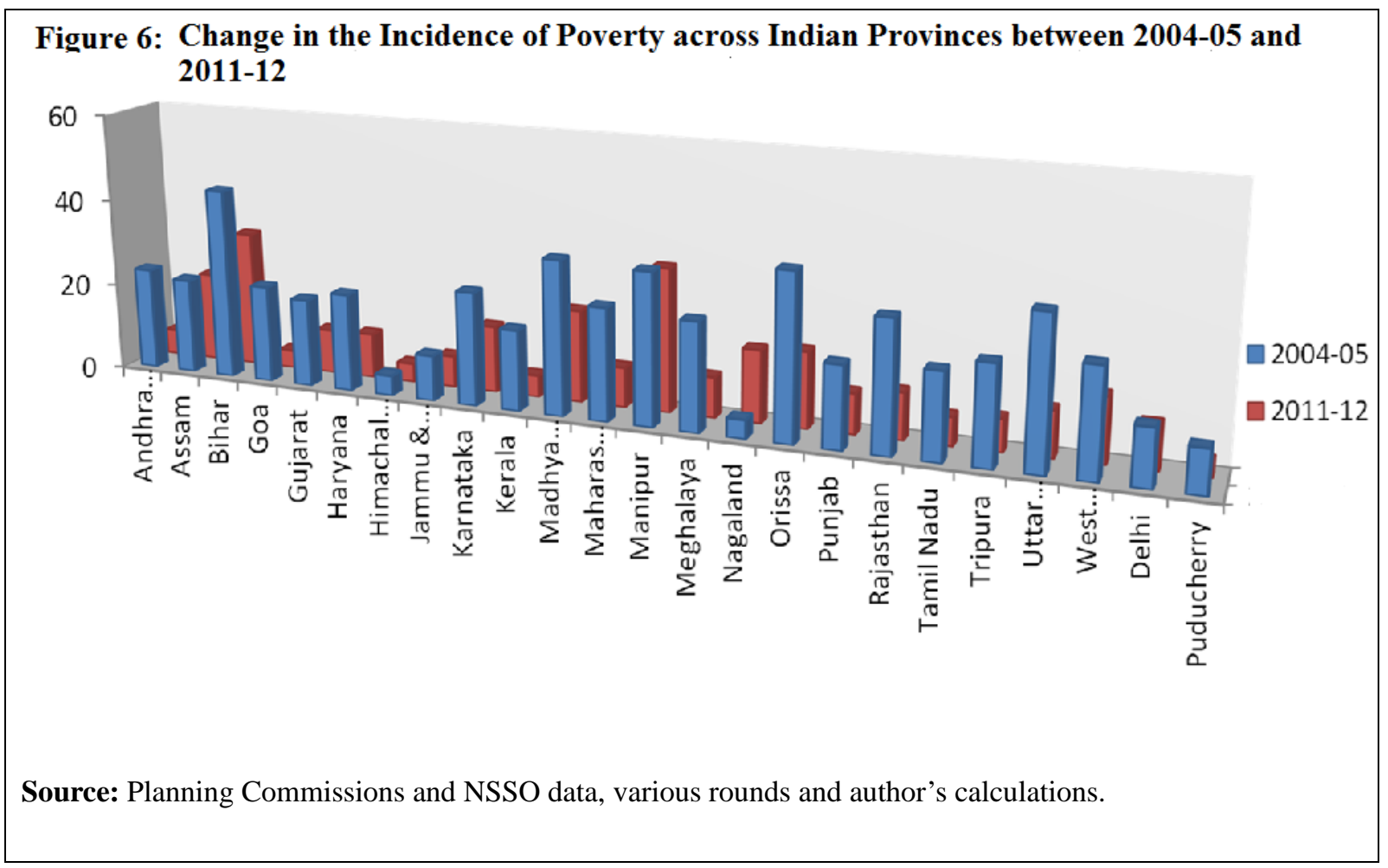

Given the concentration of informal workers in the urban economy and presence of urban poverty, the theoretical exercise will also enable to obtain an overall view of the well-being of the 'urban poor' as a consequence of productivity improvement in the urban organised nonagricultural sectors.

\subsection{Research Gap and Contribution of This Paper}

Goldberg and Pavcnik (2003) and Marjit et al. (2006) have explored the asymmetric impact of reform policies on the size of the informal sector. However, DCs like India are also plagued by capital market segmentation among the organised formal and unorganised informal sectors. It has been shown theoretically (Marjit 2003; Marjit and Kar 2004; Marjit et al. 2007a; b; Marjit and Kar 2008a; b; Marjit et al. 2008) that informal wage can change depending on various degrees of capital mobility between formal and informal sectors. These studies use simple general equilibrium structure to answer a critical question - how do 
exogenous policy changes in the formal sector affect the wage and employment conditions in the informal sector? Marjit and Kar (2009) assessed the implication of a tariff-cut in the organised formal sector on informal wages, explaining the notion of different degrees of capital mobility between informal and formal segments of the economy and how they affect the outcome on informal wage. However, while the paper by Marjit and Kar (2009) attempted to check trade policy induced relative price effects on real informal wage, this paper highlights the productivity issue explicitly.

It should be mentioned that Marjit and Kar (2008a) explored the link between labour productivity growth and informal wage, emphasising the role of capital mobility between formal and informal segments of the economy. However, it has been illustrated in different studies that informal sector firms are integrated to the formal sector firms on a contractual basis. Therefore, it would be unrealistic to assume that the informal sector produces internationally traded final goods, capital is sector-specific and that the informal and formal credit markets are completely disintegrated even in the short-run (Marjit and Kar 2008a, 2009). This is because the informal sector money-lender borrows capital from the formal credit market for re-lending. Hence a part of the formal credit enters the informal credit market. Therefore, the ‘zero mobility’ case in Marjit and Kar (2008a, 2009) papers is unlikely to happen in reality. This paper has specifically attempted to address such 'gap' in the existing research.

There has been a pertinent debate on the desirability of various types of technological progress among labour economists and trade-theorists (Jones 1996; 2003; 2006; Krugman 2000; Ethier 2005). Trade-theorists, emphasising the importance of relative factor intensities in different sectors (Jones 1965; Oladi and Beladi 2007; Beladi et al. 2008) argue that a labour-augmenting type technological change in the labour-intensive sector will push the wages up. This result is in contradiction to the usual predictions of labour economists. Findlay and Jones (2000) argued that trade and labour theory outcomes will be merged for a major modification of production structure consequent upon such a technological progress. The most recent attempt has been made by Beladi et al. (2012) in terms of a simple twosector static general equilibrium model with formal/organised (unionised wage) informal/unorganised (flexible wage) labour markets to show that technological progress leads to opposite movement in informal wage independent of relative factor-intensity ranking between organised and unorganised labour sectors. 
But the simple two-sector set-up in Beladi et al. (2012) was not quite generic to portray the conditions of urban informal sector in a developing economy. It would be more realistic to classify the urban informal sector as comprising of an industrial segment that uses labour and capital to provide an intermediate input such as leather and rubber products, electrical equipment etc. to the formal sector firm, with the urban informal firm being tied to the formal firm by the system of subcontracting. Another aspect of the informal service sector comprises producing non-traded services such as street-vendors with almost no use of capital. These possibilities have been considered in Kar and Marjit (2009).

However, Kar and Marjit (2009) did not consider any dualism in the domestic capital market. The dominant feature of dualism in the capital market is the fragmented interest rate structure, featuring lower allocation of loanable capital to the informal sector at a higher relative rental rate. The informal producers do not have access to credit from formal institutions. Therefore, they generally depend on the informal sources of credit, such as informal moneylenders, who charge exorbitantly high interest rates. Under this policy, the informal sector lenders act as financial intermediaries between the formal credit agency and the final borrowers of credit. ${ }^{5}$ This is the precise idea that has been put forward in the theoretical literature invoking the informal capital (credit) market as imperfect (for example, Basu 1984; 1988; Basu and Bell 1991; Chaudhuri 2003). This paper specifically incorporates such dualism in capital (credit) market, thus capital mobility between the formal and informal sectors is triggered by the interest rate differential between the two capital (credit) markets, departing from the existing relevant theoretical contributions in this context. In fact, this is the best possible treatment of incorporating credit market dualism in the present set-up (given that the purpose of this paper is not to determine the interest rate prevailing in the informal credit market), both from the perspectives of tractability and reliability of the results. In order to avoid paradoxical circumstances, without any loss of generality, this paper models the informal intermediate input producing sector as having Leontief production technology (and thus fixed capital requirement in production).

\footnotetext{
${ }^{5}$ The dependency of the informal moneylenders on the formal channels stems from the idea of credit-product interlinkage between the vertically integrated formal and informal establishments. The formal firms are dependent on the informal establishments for the utilisation of cheap labour in production, while the informal firms are dependent upon the formal firms for supply of credit and marketing of the product. These two motives form the rationale for the subcontracting of the formal sector production activities to the informal establishments, as evidenced in Papola (1981), Romatet (1983), Sethuraman (1984), Maldonado and Sethuraman (1992) in this context.
} 
Section 2 discusses theoretical model and the comparative static responses. Finally, Section 3 concludes.

\section{The Model}

Consider a static general equilibrium model for a small, open developing economy with four sectors: two urban formal sectors and two urban informal sectors. Among the two informal sectors, one is an informal service sector (Sector 1) providing non-traded services by the unskilled (surplus) labour of the economy. Another sector (Sector 2) is within the industrial set-up, producing a non-traded intermediate input using unskilled labour and capital for the formal export sector. Within the formal segment, the export sector (Sector 3) uses skilled labour ${ }^{6}$, capital, the domestically produced intermediate input and an imported 'middle product' $\left(M\right.$, price $\left.P_{M}^{*}\right)$ a' la Sanyal and Jones (1982) in its production process. $M$ could be viewed as an array of foreign technology-embedded inputs (e.g. computer data storage units, automatic data processing machines and so on, which cannot be supplied by the local firms) for the skilled labour - intensive service sector, Sector $3 .^{7}$ Hence, Sector 3 producers are using both local and imported intermediate inputs. Skilled wages are fixed at a higher level by prior negotiations with labour unions. I do not explicitly model wage-fixation given the focus of this paper, treating skilled wages as institutionally given. ${ }^{8}$ Sector 4 is the importcompeting sector of the economy using just skilled labour and capital in production.

\footnotetext{
${ }^{6}$ Here 'skill' does not imply only human capital. In fact, the labourers in the formal sectors are distinguished from the informal sector workers in terms of productivity. Thus 'skilled labour' refers to the combination of wage-earners, mangers, supervisors and clerical job-performers in the organised sector. 'Skilled wage' here means the total wages and salaries paid to 'skilled labour', which includes the payments to the managers and supervisors.

${ }^{7}$ It is well-known that there is a range of productive activities wherein productive resources and raw materials are transformed into final commodities ready for consumption, so that the role of international trade is to convert products available in early stages of production into a different set of products more useful as inputs to produce the final goods required by the consumers. That is, international trade takes place in the 'middle' of the production process. As illustrated in Sanyal and Jones (1982), the 'Input Tier' combines local resources to produce a set of 'middle products', which then get traded for other middle products, which, in turn, will be used as inputs in the 'Output Tier' of the economy, producing the final consumer goods. Let us assume here for simplicity that there is only one production activity in the Input Tier to produce a middle product $E$ that gets exchanged in the world market for the middle product $M$, which is combined with skilled-labour and capital in the Output Tier (i.e. in import-competing formal industry sector 4) to produce the import-competing product commodity 4.

${ }^{8}$ For a similar treatment of unionised wage in the organised sector, see Mukherjee (2012, 2014). Chaudhuri (2003) has provided an explanation regarding how the unionised wages can be determined through the collective bargaining process.
} 
Countries such as India export primarily skilled labour - intensive products, while they are the net importers of relatively more capital-intensive but less skilled labour - intensive manufacturing products. Therefore, this paper assumes that Sector 4 is the relatively capitalintensive sector in the economy. Production functions in Sectors 3 and 4 follow constant returns to scale (CRS) technology, whereas those in Sectors 1 and 2 are of fixed-coefficient type. 
Table 1: The Model Characteristics

\begin{tabular}{|c|c|c|c|c|c|}
\hline \multirow[t]{2}{*}{ No of Sectors } & \multicolumn{2}{|c|}{ Sector Definitions } & \multicolumn{2}{|c|}{ Factor Markets } & \multirow{2}{*}{$\begin{array}{c}\text { Relative Factor-intensity } \\
\text { Ranking }\end{array}$} \\
\hline & Non-traded & Traded & Labour Market & Capital Market & \\
\hline \multirow[t]{2}{*}{4} & $\begin{array}{l}\text { Sector } 1 \rightarrow \\
\text { - } \quad \text { Finished non-tradable producing } \\
\text { sector; absorbs surplus labour } \\
\text { among the migrants coming to } \\
\text { city; represents very low-skilled } \\
\text { activities such as domestic help or } \\
\text { small vendors with little or no use } \\
\text { of capital. } \\
\text { - Leontief Production technology. }\end{array}$ & $\begin{array}{l}\text { Sector } 3 \rightarrow \\
\text { - } \quad \text { Export sector, vertically } \\
\text { integrated with sector 2, use } \\
\text { (relatively) skilled labour and } \\
\text { capital, along with the } \\
\text { 'middle product' imported } \\
\text { from the ROW and the local } \\
\text { inputs supplied by Sector } 2 . \\
\text { - CRS production function. }\end{array}$ & $\begin{array}{l}\text { 'Informal’ Labour Market in } \\
\text { Sectors } 1 \text { \& } 2 \rightarrow \text { Competitive } \\
\text { (unskilled) labour market with } \\
\text { flexible wages (unskilled). }\end{array}$ & $\begin{array}{l}\text { Imperfect capital (credit) } \\
\text { market in informal sectors } \\
\text { (Sectors } 1 \text { \& 2) } \rightarrow \text { Interest rate } \\
\text { is steeply higher from the one } \\
\text { prevails in the formal } \\
\text { competitive credit market. } \\
\text { Capital (credit) allocated to the } \\
\text { informal sector is positively } \\
\text { related to the return differential } \\
\text { between the two (informal \& } \\
\text { formal) credit markets. }\end{array}$ & \multirow{2}{*}{$\begin{array}{l}\text { Only applicable for the traded } \\
\text { formal sectors, Sectors } 3 \text { \& } 4 \text { - } \\
\text { that is, the sectors using two } \\
\text { common factors - Skilled } \\
\text { Labour \& Capital - therefore, } \\
\text { forming the required } \\
\text { Heckscher-Ohlin 'Nugget'. } \\
\text { - Sector } 3 \text { (export sector) is } \\
\text { relatively skilled-intensive } \\
\text { than_Sector } 4 \text { (import- } \\
\text { competing sector) (with } \\
\text { respect to capital). } \\
\text { No factor-intensity } \\
\text { reversal. }\end{array}$} \\
\hline & $\begin{array}{l}\text { Sector } 2 \rightarrow \\
\text { - } \quad \text { Non-agricultural intermediate } \\
\text { input producing sector, using } \\
\text { relatively unskilled labour and } \\
\text { capital, providing intermediate } \\
\text { inputs ranging from leather and } \\
\text { rubber products to electronic } \\
\text { equipment to the export sector } \\
\text { (Sector 3). } \\
\text { - } \quad \text { Leontief Production technology. }\end{array}$ & $\begin{array}{l}\text { Sector } \mathbf{4} \rightarrow \\
\text { - } \quad \text { Import-competing sector; } \\
\text { uses skilled labour and } \\
\text { capital. } \\
\text { - } \quad \text { CRS production function. }\end{array}$ & $\begin{array}{l}\text { 'Formal' (Skilled) Labour } \\
\text { Market in Sectors } 3 \text { \& } 4 \rightarrow \text { Rigid } \\
\text { (skilled) Labour Market in formal } \\
\text { sectors (Sectors } 3 \text { \& 4) with } \\
\text { institutionally given higher } \\
\text { (skilled) wage fixed by prior } \\
\text { negotiations (however, the wage- } \\
\text { bargaining is not explicitly } \\
\text { modelled given the focus of the } \\
\text { model). }\end{array}$ & $\begin{array}{l}\text { Perfect credit market in } \\
\text { formal sectors (Sectors } 3 \text { \& 4) } \\
\rightarrow \text { Competitive credit market } \\
\text { with market-determined interest } \\
\text { rate. }\end{array}$ & \\
\hline
\end{tabular}


The following symbolisations are used:

$W=$ competitive informal wage rate for unskilled labour $(\bar{L})$;

$W_{S}^{*}=$ Institutionally given skilled wage rate in formal segment of the economy;

$R=$ rate of interest in the informal credit market;

$r=$ rate of interest in the formal credit market;

$a_{j i}=$ amount of the $j^{\text {th }}$ factor used to produce 1 unit of the $i^{\text {th }} \operatorname{good}(j=L, S, K ; i=1,2,3,4)$;

$a_{23}=$ per-unit requirement of the non-traded intermediate input in Sector 3;

$a_{M 3}=$ per-unit requirement of the imported input in Sector 3;

$A=$ state of technology in the production of good 3;

$\bar{K}=$ given total stock of capital in the economy;

$\bar{S}=$ given stock of skilled labour in the economy;

$K_{1}=$ available capital in informal sector (endogenous, depends on formal-informal interest rate differential);

$P_{i}=$ domestic prices of non-traded goods $(i=1,2)$;

$P_{i}^{*}=$ internationally given prices of traded goods $(i=3, M, 4)$;

$\theta_{j i}=$ cost-share of factor $j$ in the production of good $i$;

$\lambda_{j i}=$ share of sector $i$ in the total employment of factor $j$;

$t=$ ad valorem rate of tariff imposed on the import of $M$;

$T=$ ad valorem rate of tariff imposed on the import of $X_{4}$;

$\Lambda=$ proportional change.

Price-unit cost equality in competitive product markets entail the following four equations

$$
W a_{L 1}=P_{1}
$$




$$
\begin{aligned}
& W a_{L 2}+R a_{K 2}=P_{2} \\
& W_{S}^{*} a_{S 3}+r a_{K 3}+P_{2} a_{23}+a_{M 3} P_{M}^{*}(1+t)=P_{3}{ }^{*}
\end{aligned}
$$

Where $P_{M}^{*}(1+t)=P_{M}$ is the domestic price of $M$. Also we have,

$$
\begin{aligned}
& a_{S 3}=a_{S 3}\left(\frac{W_{S}{ }^{*}}{r}, A(t)\right), \text { with } \frac{\partial a_{S 3}}{\partial\left(\frac{W_{S}{ }^{*}}{r}\right)}<0, \frac{\partial a_{S 3}}{\partial A}<0, \frac{\partial A}{\partial t}<0 . \\
& W_{S}{ }^{*} a_{S 4}+r a_{K 4}=P_{4}{ }^{*}(1+T)
\end{aligned}
$$

Equation (3.1) states that the labour-output ratio is a decreasing function of both the wagerental ratio in sector 1 as well as the state of technology while the latter is another negative function of the ad valorem rate of tariff imposed on the imports of $M$. Tariff reduction on the imports of capital goods implies greater access towards increased varieties of foreigntechnology embedded imported input $(M)$, thereby lowers skilled labour - output ratio in Sector $3\left(a_{S 3}\right)$. However, it does not disturb the capital-output ratio in Sector $3\left(a_{K 3}\right)$.

The following functional relationship between $R$ and $r$ is assumed

$$
R=\rho r ; \rho>1
$$

Here $\rho$ denotes the degree of imperfection of the informal credit market; $\rho>1$ implies that $R>r$. This is because the informal moneylenders generally borrow funds from the formal sector at the market rate of return $r$, re-lend it to the informal borrowers and in this way maximise the net interest income. ${ }^{9}$ Therefore, it is realistic to assume that informal interest rate is positively related to and steeply higher than the formal interest rate. The lower the number of alternative sources of credit to the borrowers in the informal sector, the higher is the degree of imperfection in the informal credit market. And thereby, the higher is the power of the informal sector lenders to mark up interest rate in the informal credit market over the one in the formal capital market (i.e. the greater the value of $\rho$ ).

Using (5), Equation (2) can be written as

$$
W a_{L 2}+\rho r a_{K 2}=P_{2}
$$

Equations (1), (2.1), (3), (4) are the price-unit cost equality conditions for the informal service sector, intermediate input producing sector, the export (formal) sector and the import-

\footnotetext{
${ }^{9}$ Thus $r$ could also be interpreted as the opportunity cost of lending credit to the moneylender.
} 
competing manufacturing sector, which is relatively capital intensive compared to the vertically integrated export sector.

It is also assumed that the amount of credit allocated to the informal sector is a positive function of the return differential between the two capital markets. Therefore as long as $\rho>$ 1, informal capital market exists and thus the dichotomy between the two credit markets exists.

$$
K_{1}=K_{1}(R-r)=K_{1}\{r(\rho-1)\} \text {. So when }(R-r) \geq 0, K_{1}^{\prime}(.) \geq 0 \text {. (6) }
$$

Thus, full utilisation of informal credit implies

$$
a_{K 2} X_{2}=K_{1}\{r(\rho-1)\}
$$

Note that Equation (7) is not an independent equation since it only states that part of the available credit is allocated to the informal credit market. ${ }^{10}$

The two urban formal sectors use the formal credit. The equilibrium in the formal credit market ensures that

$$
a_{K 3} X_{3}+a_{K 4} X_{4}=\bar{K}-K_{1}\{r(\rho-1)\}
$$

The presence of foreign capital has been assumed away in the economy’s capital endowment.

The full employment conditions of unskilled and skilled labour imply respectively

$$
\begin{aligned}
& a_{L 1} X_{1}+a_{L 2} X_{2}=\bar{L} \\
& a_{S 3} X_{3}+a_{S 4} X_{4}=\bar{S}
\end{aligned}
$$

The demand-supply equality condition for the non-traded input gives

$$
a_{23} X_{3}=X_{2}
$$

I assume that per-unit requirements of the local intermediate input and imported inputs are constant in Sector 3. ${ }^{11}$

\footnotetext{
${ }^{10}$ For similar treatment see Chaudhuri (2003, 2010).

11 This assumption rules out the possibility of substitution between the non-traded intermediary and other factors of production in sector 3 . This is the widely used assumption in the static general equilibrium literature (such as Gupta 1994; Chaudhuri 2003 and many more). This can be justified by the fact that one Brown Tube is used for a TV set. In industries like shoe-making and garments, large formal sector firms farm out their production to the small informal sector firms under the system of subcontracting. So the production is done in the informal sector
} 
Table 2: The General Equilibrium System

\begin{tabular}{|c|c|c|c|c|c|}
\hline \multicolumn{3}{|c|}{ VARIABLES } & \multicolumn{2}{|c|}{$\begin{array}{c}\text { KEY EQUATIONS DESCRIBING THE } \\
\text { MODEL }\end{array}$} & \multirow[b]{2}{*}{$\begin{array}{l}\text { SIMPLIFYING } \\
\text { ASSUMPTIONS }\end{array}$} \\
\hline ENDOGENOUS & $\begin{array}{c}\text { EXOGENO } \\
\text { US }\end{array}$ & $\begin{array}{c}\text { POLICY- } \\
\text { PARAMETE } \\
\text { RS }\end{array}$ & $\begin{array}{c}\text { PRICE } \\
\text { SUBSYSTE } \\
\text { M (PRICE = } \\
\text { UNIT } \\
\text { COST) }\end{array}$ & $\begin{array}{l}\text { QUANTITY (OUTPUT) } \\
\text { SUBSYSTEM (FULL } \\
\text { EMPLOYMENT/UTILI } \\
\text { SATION OF FACTORS) }\end{array}$ & \\
\hline $\begin{array}{c}W, r, P_{1}, P_{2}, K_{1}, X_{1}, X_{2}, X_{3}, \lambda \\
\text { Note that, } K_{1}= \\
K_{1}(r(\rho-1)) \text {, with } \\
K_{1}^{\prime}(.)>0\end{array}$ & $\begin{array}{c}W_{S}{ }^{*}, \bar{K}, \bar{L} \& \\
\bar{S}\end{array}$ & $t>0, \rho>1$ & $\begin{array}{l}\text { Equations } \\
\text { (1), (2.1), } \\
\text { (3), (4) }\end{array}$ & Equations (6), (8) - (11). & $\begin{array}{c}a_{23} \& a_{M 4} \text { are } \\
\text { constant }\end{array}$ \\
\hline
\end{tabular}

The general equilibrium system sketched above comprises nine independent equations, namely Equations (1), (2.1), (3), (4), (6), (8)-(11) to solve for nine endogenous variables: $W, r, P_{1}, P_{2}, K_{1}, X_{1}, X_{2}, X_{3}$ and $X_{4}$; given the parameters, namely the world prices of commodities 3 and $4, W_{S}{ }^{*}, t, \rho, \bar{K}, \bar{L}$ and $\bar{S}$. The four price variables can be solved in the following way. $r$ is determined from Equation (4) given the unionised skilled wage and exogenous price of the importable. Given $r$, one can determine $P_{2}$ from Equation (3) and given the policy-parameter $\rho$, substituting $r$ and $P_{2}$ in Equation (2.1) one can obtain $W$. Finally from Equation (1) $P_{1}$ is found by substituting $W$. Once factor prices are known, factor-coefficients $a_{j i}$ s are also known. Therefore, using the value of $r$ and given $\rho$, one can find $K_{1}($.$) from Equation (6). Then simultaneously solving Equations (8) and (10) X_{3}$ and $X_{4}$ are determined. After that, $X_{2}$ is solved from Equation (11). Finally, substituting $X_{2}$ in Equation (9), $X_{1}$ gets solved.

firms while labelling, packaging and marketing are done by the formal sector firms. One pair of shoes produced in the informal sector does not change in quantity when it is marketed by the formal sector as a final commodity. Thus there remains a fixed proportion between the use of the intermediate input and the quantity of the final commodity produced and marketed by the formal sector. 


\subsection{Comparative Static Exercises ${ }^{12}$}

Let us now explore the implications of factor-specific technological progress in Sector 4, ceteris paribus, on the urban informal workers. This can be summarised in the following proposition.

Proposition 1. Factor-specific technological progress in the relatively capital-intensive formal sector ceteris paribus, unambiguously raises formal and informal interest rates but reduces wages in both informal sectors. However, as a result of either a capital-saving or a capital-using technological progress in the capital-intensive import-competing formal sector, the intermediate input producing informal sector may contract but the finished non-tradable producing informal sector may expand in terms of both output and employment.

Remarks: If the relatively capital-intensive import-competing formal segment (Sector 4) undergoes capital-saving technological progress, it will raise only the formal interest rate (given the fixed skilled wage and fixed price of the imported intermediate product). As a result of this, the transformation schedule of the Heckscher-Ohlin (HO) 'nugget' shifts outward, with expansion of the output of the capital-intensive Sector 4 and contraction of the output of relatively (skilled) labour-intensive Sector 3, along with the reduced (skilled) wagerental ratio at the new production point on the new transformation schedule, naturally with different slope than the initial equilibrium point. Noticeably, such technological progress contributes to the cost-saving of the relatively capital-intensive industry in the nugget (Sector 4) by changing the zero-profit condition in Equation (4), like subsidising the industry, and to the relative surplus of capital in the HO 'nugget' given the product-mix.

Therefore, the demand for non-traded intermediate input falls given the supply. This reduces the price of the intermediate input $\left(P_{2}\right)$, whereas rental costs paid by the informal producers rise (since the formal interest rate goes up). As a result, from the zero-profit condition of Sector 2 (the intermediate input producing sector), it is clear that competitive unskilled wage rate should fall. At the same time, since intermediate input is used in a fixed proportion in the export sector production, which cannot be supplemented by other factors of production in Sector 3, this implies that Sector 2 must shrink as well. Hence Sector 2 releases unskilled

12 The detailed algebraic results are available in Appendix I. 
labour to be absorbed in sector 1 , but at a lower competitive wage than before. Let us call it the 'first round' effect.

However as $r$ rises, $(R-r)=r(\rho-1)$ goes up as well. This depresses the supply of capital to the formal capital market, inducing a Rybczynski effect in the nugget that tends to expand Sector 3 and Sector 2 given and let us term it as the 'second round' effect. However, as long as the proportion of capital reallocated to the informal sector falls short of the proportion of capital used in Sector 4, the 'first round' effect dominates ${ }^{13}$ and both Sector 3 and Sector 2 may contract as a consequence. If that happens, then the finished non-tradable producing informal sector (Sector 1) would expand and the retrenched workers from Sector 2 would join Sector 1. However, such outcome would be welfare reducing from various points:

a) The downward pressure on wages of informal workers has a clear impact on aggravating poverty in the urban areas. This is because a large share of the urban poor in developing countries (such as above 78\% in India) work in the informal sector and any reduction in the wages of the informal workers may significantly increase the incidence of poverty.

b) Sector 2 contracts in terms of both output and employment. Hence workers are forced to leave the unregulated manufacturing firms and take up insecure non-traded service sector jobs with lower earnings and hence greater likelihood of poverty.

In case of a (skilled) labour -saving (i.e. capital-using) technological progress in the capitalintensive Sector 4; there is now a relative surplus of skilled labour in the HO 'nugget' given the product-mix, which helps the vertically integrated (skilled) labour-intensive Sector 3. However, increase in the capital cost of production in Sector 3 (due to the increase in $r$ ) discourages Sector 3 producers to expand thereby lowering the demand for $X_{2}$ and hence $P_{2}$ and competitive unskilled wage (informal) fall unambiguously. But there will also be another channel of impact, namely the increase in formal-informal interest rate differential (due to the increase in formal interest rate) that should also help the vertically integrated sectors (Sector 2 and Sector 3) to expand. However, as long as the net credit availability in the HO nugget remains positive and $\hat{r}$ has a lower bound; Sector 3 may contract in this case as well.

(Q.E.D.)

\footnotetext{
${ }^{13}$ The algebraic proof of this is laid in Appendix I.
} 
As discussed in the introductory section, owing to the lowering of input tariffs during the liberalised regime in the skill-intensive Indian service industries, greater access towards increased varieties of foreign-technology embedded imported input $(M)$ calls for capitalusing (i.e. skilled labour -saving) technological progress in the skill-intensive Sector 3. Therefore, it would be sufficient (given the focus of this paper) to trace out the implications of a capital-using technological progress (brought about by uniform tariff reduction on imports of $M$ ) in Sector 3, ceteris paribus, on informal sector wage and employment conditions.

Proposition 2. A uniform tariff reduction on the imported input in the export sector, ceteris paribus, induces a capital-using technological progress in that sector, resulting expansion in product prices and competitive real unskilled wage of the informal workers in the two informal sectors. However, the unskilled workers now move to the local intermediate input producing informal sector since this sector expands in terms of both output and employment at the cost of the finished non-tradable producing informal sector.

Remarks. Since the return to capital in the formal sector, $r$, is already determined from the zero-profit condition for Sector 4; a capital-using technological progress in Sector 3, brought about by the uniform tariff reduction on the imports of capital goods as inputs, acts like an increase in the price of commodity 3, or more accurately, like a set of industry subsidies. Therefore, there is now a parallel outward shift of the transformation schedule of the HO 'nugget', with higher $X_{3}$ and lower $X_{4}$, for the same (skilled) wage-rental ratio at the new production point on the new transformation schedule. Hence, the excess demand for the product of Sector 2 (by Sector 3 producers) contributes to an increase in $P_{2}$. However, $a_{L 1}$ and $a_{j 2}$ s do not change $(j=L, K)$ (owing to the fixed-coefficient production technology in Sectors 1 and 2). Therefore, Sector 2 expands unequivocally and unskilled labourers are reallocated from Sector 1 to Sector 2. Thus, Sector 2 expands both in terms of output and employment at the cost of Sector 1. From the zero-profit condition of Sector 2, it is imminent that the real informal wage increases.

It is also evident in this framework that if government would intervene aiming to reduce the degree of imperfection in informal credit market and hence the informal rental return (by 
reducing $\rho$, ceteris paribus), ${ }^{14}$ that would tend to reduce the capital-cost of production for intermediate input producers. However, this would also bring down the formal-informal interest rate differential to some extent and prevent credit reallocation towards informal sector. Nonetheless, from the zero-profit condition for the intermediate input producing sector, it is clear that this would contribute positively to the increase in informal wage. ${ }^{15}$

\subsubsection{Capital-using Technological Progress in the Formal Sectors and Informal Wage Response - A Quantitative Analysis}

Let us now examine the implication of a capital-using technological progress at the rate $\alpha>$ 0 in sector 3 and at the rate $\gamma \alpha>0$ in sector 4 on the informal wage, ceteris paribus. ${ }^{16}$ Subsequently, total differentiation of Equations (1), (2.1), (3)-(4), application of envelope conditions and use of Cramer's rule yield:

$$
\begin{gathered}
\widehat{W}=\frac{\alpha}{\theta_{K 4} \theta_{L 2}}\left\{\left(\frac{\theta_{S 3} \theta_{K 4}-\gamma \theta_{K 3} \theta_{S 4}}{\theta_{23}}\right)-\gamma \theta_{K 2} \theta_{S 4}\right\}=\frac{\alpha}{\theta_{K 4} \theta_{L 2} \theta_{23}}\left[\theta_{S 3} \theta_{K 4}-\gamma \theta_{S 4}\left(\theta_{K 3}+\theta_{K 2} \theta_{23}\right)\right] \\
=\frac{\alpha}{\theta_{K 4} \theta_{L 2} \theta_{23}}\left[\theta_{S 3} \theta_{K 4}-\gamma \theta_{S 4} \widetilde{\theta_{K 3}}\right]
\end{gathered}
$$

\footnotetext{
${ }^{14}$ Government intervention aiming to integrate the formal and informal credit institutions through appropriate linkages is the most feasible way to achieve this. Since credit is not directly accessible from formal sources, the focus should lie on the provision of microfinance and related services to informal sector enterprises, strengthening of the institutional framework in this area, creation of alternative sources of credit and developing alternative delivery mechanisms. Most of these interventions in different countries have focused on alleviating credit constraints for the rural poor, but some have also targeted the urban poor. Among these, the following are widely known: Grameen Bank in Bangladesh; Bank Rakyat Indonesia (BRI); and Prodem (the Fundaci' on para la Promocíon y Desarrollo de la Microempresa) in Bolivia. (See Jackelen and Rhyne, 1991 for details). Apart from governmental initiatives, self-help groups can also have a considerable role in alleviating the problem of obtaining credit. A self-employed women's association (SEWA) in Ahmedabad and the Working Women's Forum (WWF) in Madras (both in India) have created their own banks along the lines of cooperatives to cater to the credit needs of poor women; they follow mechanisms similar to those described above and reach well over half a million people.

${ }^{15}$ Another possible relevant way of incorporating credit market dualism would be to consider the case where the borrowers in the informal sector get an additional loan at higher cost, i.e. the interest rate on informal credit is a positive function of the amount of capital borrowed, $a_{K 2} X_{2}$ (see Chaudhuri, 2010 Chapter 3 in this context). This would yield $\left[d R(.) / d\left(a_{K 2} X_{2}\right)\right]>0$. It is straightforward to show in the present set-up that $\widehat{W}=$ $-\left(\theta_{K 2} / \theta_{L 2}\right)\left(a_{K 2} X_{2} / R\right)\left[d R(.) / d\left(a_{K 2} X_{2}\right)\right] \widehat{X_{2}}$, which is negative (positive) if the intermediate input producing sector, sector 2 expands (contracts). But that means changes in demand for unskilled workers in informal sectors would not have any role in driving the informal wage-movement, which is unrealistic and inconsistent given the empirical evidence on India discussed at the beginning. Therefore, this paper does not consider this formulation of credit market imperfection in the informal sector in the present context.

${ }^{16}$ It should be noted that the capital-using technical progress in Sector 3 is not endogenised in this numerical exercise for clarity. This is perfectly fine for this static (long-run) model, since endogenising the technical progress would only imply a positive change in the intercept (i.e. technology component) and does not change the working of the model and the results qualitatively.
} 
Where $\widetilde{\theta_{K 3}}=\theta_{K 3}+\theta_{23} \theta_{K 2}$ represents the share of capital costs in sector 3 for both its direct and indirect use of capital. $|\theta|=\left(\theta_{K 4} \theta_{S 3}-\widetilde{\theta_{K 3}} \theta_{S 4}\right)>0$ if the vertically integrated sector 3 is relatively less capital-intensive than sector 4 in value-terms.

One can use Equation (12) to quantify the relationship between productivity change in the formal sectors and changes in informal wage. However, it is evident that Equation (12) leads to a linear relationship between $\widehat{W} \& \alpha$. Let us assign the following parameter values for the initial equilibrium according to the assumptions in the model in a close approximation to the actual data for India.

\section{Table 3: Parameters for the Initial Equilibrium}

Parameters

$\theta_{L 2}$

$\theta_{K 2}$

$\theta_{K 3}$

$\theta_{S 3}$

Cost-share of skilled-labour in the export sector

Cost-share of intermediate input in the export sector, defined as the ratio of value-added by the subcontracting activity (defined in Sub-section 1.1) to the value-added in organised sectors

$\theta_{S 4}$

$\theta_{K 4} \quad$ Cost-share of capital in the import-competing sector

Cost-share of middle products in import-competing sector,

$\theta_{M 4} \quad$ approximated as average import intensity of the importing firms during 2001-02 in India
Values

0.7

$0.3=\left(1-\theta_{L 2}\right)$

0.4

0.5

0.1 (constant)

0.2 (constant)

Source: Abraham 2010, Berman et al. 2005, Marjit and Kar 2008, Marjit et al. 2011, Seker and Rodriguez-Delgado (2011), ASI and NSSO surveys: various rounds.

Now, we shall consider three alternative values for $\gamma$, namely $0.5,1.0$ and 2 . In all the cases skilled labour in both the sectors undergo technological progress; but in the first case, productivity of the skilled labour in sector 3 becomes double to the one in sector 4 . Similarly, 
in the second case, productivity of the skilled labour in sector 3 has increased at the same rate to the productivity improvement of the skilled labour in sector 4. In the third case, productivity of the skilled labour in sector 4 becomes double to that in sector 3 .

\section{Figure 6: Capital-using Technical Progress in Formal Sectors $(\alpha)$ and Growth in Informal Wage}

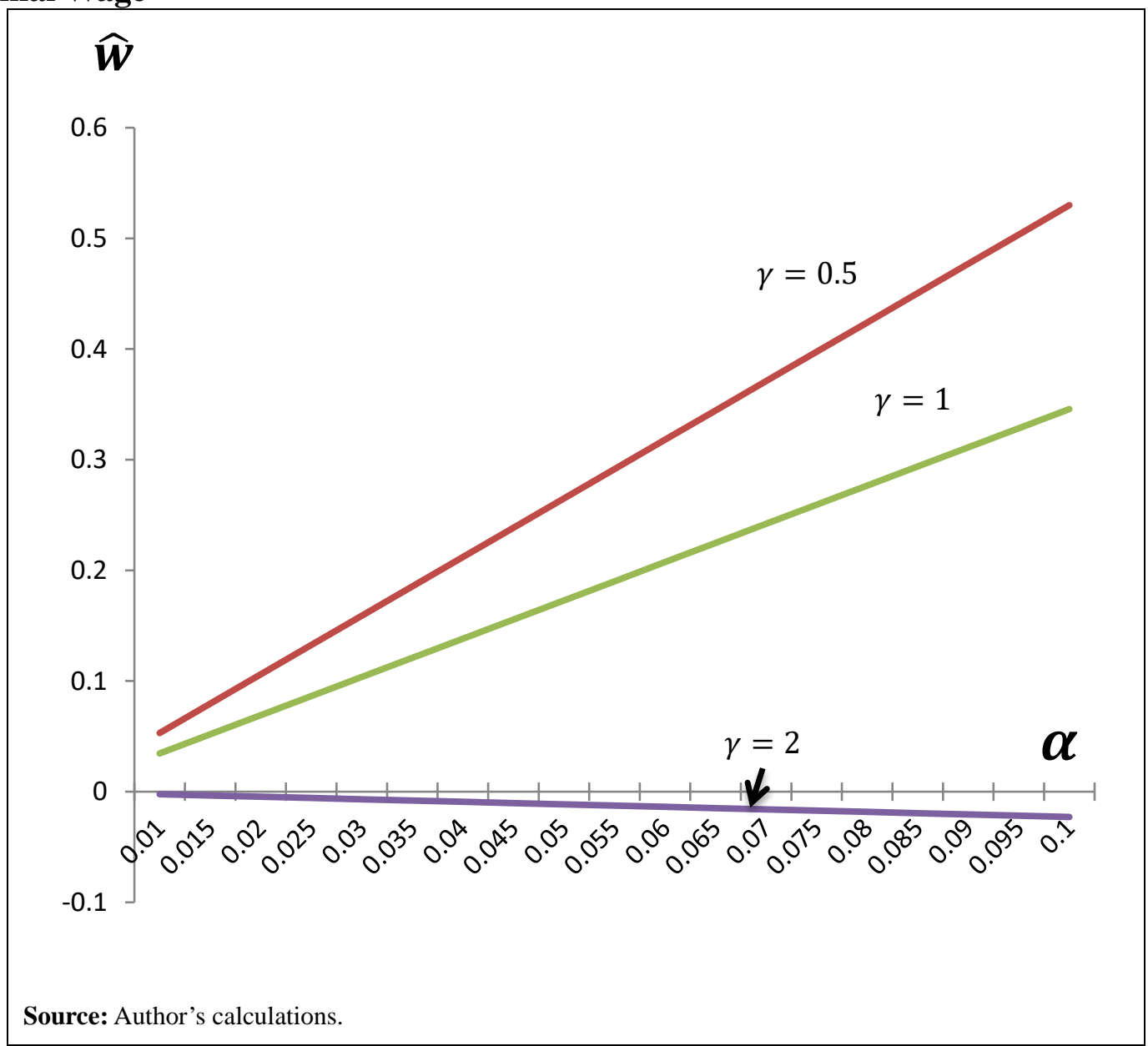

In Equation (12), the relationship between technological progress in the formal sectors and change in informal wage is governed by the sign of the term in third bracket, viz., $\left(\theta_{S 3} \theta_{K 4}-\right.$ $\left.\gamma \theta_{S 4} \widetilde{\theta_{K 3}}\right)$. With $\gamma=1$, this term becomes nothing else but the net relative factor-intensity rankings of the two formal sectors in the nugget in value-terms, which is positive according to our assumption of relative factor-intensity ranking in the nugget. Hence, both the formal sectors in the nugget use less labour (skilled) in per-unit of production. This means, the relatively (skilled) labour-saving Sector 3 expands at the expense of Sector 4. Subsequently, some of the capital flows to the informal sector and the real informal wage increases. 
With $\gamma=2$, the productivity of skilled labour in Sector 4 becomes double to that in Sector 3, which hurts the relatively skilled labour -intensive vertically integrated Sector 3. This is because the relative extent of cost reduction in the use of skilled labour is now lesser in Sector 3 within the HO nugget. Although some capital will be reallocated towards the informal sector, the 'first-round effect' (mentioned in relation to Proposition 1) dominates and subsequently, decline in real informal wage is observed with the capital-saving technological progress.

However, when $\gamma=0.5$; the relatively (skilled) labour-intensive vertically integrated Sector 3 expands at the expense of Sector 4, capital reallocates towards the informal sector and we observe sharp increase in real informal wage.

The quantitative analyses in Section 2.1.1 would have been qualitatively similar in case of capital-saving technological progress in the two formal sectors for $\gamma=1$, since in either of the two types of factor-biased technological progress, the (skilled) wage - rental ratios are changing in the same direction, given that both $X_{3}$ and $X_{4}$ are produced in the initial and final equilibrium points. However, with capital-saving progress, Sector 3 would expand now in the nugget for $\gamma=2$ and consequently informal wage increases; while for $\gamma=0.5$, Sector 3 would contract and real informal wage declines.

\section{Concluding Remarks}

This paper investigates the implications of productivity surge in the formal sectors of the economy on the wellbeing of the workers in urban informal sectors using a four-sector general equilibrium model with labour and capital market distortions. The present research stems from the observation that the 1991 economic reform in India has contributed to the technological improvement in the organised sectors which has been quite substantial over the recent years. Albeit the existence of strong production inter-linkage between formal and informal sectors; the concurrency of productivity take-offs in the organised sectors and sharp increase in informal wages in recent years still remains a puzzle since both capital and labour flow to the informal sectors. Hence, in order to propose a plausible answer to this puzzle, this 
paper investigates the general equilibrium implications of trade-induced technological progress in the formal non-agricultural sectors of the economy on the urban informal wages with segmentation in factor markets.

In this simple general equilibrium model, the urban formal sectors wages are pegged at a higher level than competitive wages by prior negotiations with labour unions; while dualism in the capital market is characterised by the fragmented interest rate structure, featuring lower allocation of loanable capital to the informal sector at a higher relative rental rate. Informal sector producers, however, use capital and labour in fixed proportions. The inter-linkage between the formal and informal credit markets (that has been evidenced and demonstrated in different theoretical and empirical literature), has been ignored in earlier related works (Kar and Marjit 2009; Marjit and Kar 2008a; 2009) in course of examining the impact of trade reform measures in the formal sectors on the informal wages in such four-sector general equilibrium model in presence of finished non-tradable and non-traded intermediate inputs.

In sum, the present research highlights the importance of credit-product inter-linkage between the urban formal and informal non-agricultural industries in order to trace out the implications of trade-induced productivity surge in the formal sectors on the wages and employment conditions of the economically marginalised urban workers working under informal arrangements.

The policy implications of the present analysis are straightforward to infer. It has already been discussed in the text that reform, induced by government intervention, in the informal sector credit market tends to prevent capital reallocation towards informal sector in this framework. On the other hand, reform in the formal sector labour market would reduce the net returns to the formal sector workers and thus, owing to the productivity improvement in the formal sectors, increase in the interest rate prevailing in the formal sectors would be more pronounced in that scenario and therefore, formal-informal interest rate gap would be more widened in this context, leading to a greater reallocation of capital from formal to the informal sectors.

Moving to the issue of empirical testability of the key relationships identified in the theoretical model, one needs to narrow down attention to longitudinal sector (industry) specific data for formal and informal production activities. However, such empirical analysis is presently beyond the scope of this paper, primarily due to the unavailability of suitable and adequate data for India, although the available limited sample has been utilised to provide a 
set of stylised facts to motivate the theoretical analysis of this paper. Moreover, it is another challenge to construct any direct measure of capital (credit) allocation between formal and informal industries, using the secondary survey data on informal sector available from National Sample Surveys (NSS). These issues have been laid for future research.

But this paper has undoubtedly been able to addresses the crucial policy-question, which is often the subject of intensive debate: whether and under what economic conditions could the benefits of productivity improvement in the formal sectors would trickle down to the marginalised workforce in the urban areas working in so-called 'informal sectors' (through the impact on their real wages and employment conditions).

\section{Acknowledgement}

This is an excerpt of my Doctoral dissertation (approved for $\mathrm{PhD}$ ) at the University of Nottingham (UK). I am grateful to Prof Oliver Morrissey, Prof Chris Milner, Prof Catia Montagna, two anonymous referees and the Editor (Prof Hamid Beladi) of the International Review of Economics and Finance for their constructive comments on the earlier version of the paper. The paper has been communicated in the conferences of Delhi School of Economics, Indian Institute of Foreign Trade, Indian Statistical Institute (New Delhi) and University of Nottingham (UK). I am also grateful to Ms S Zafar for her help in the earlier versions. The usual disclaimers are applicable.

\section{APPENDIX - I}

\section{Proof of Proposition 1}

Let us assume Sector 4 undergoes capital-saving technological progress by $\alpha>0$, ceteris paribus. Totally differentiating Equations (1) - (4); applying 'envelope conditions' ${ }^{17}$ and using Cramer's rule one can obtain

\footnotetext{
17 This stems from the fact the competitive producers in each sector choose techniques of production in order to minimise unit costs of production. See Caves et al. (2002) for details.
} 


$$
\left(\begin{array}{cccc}
\theta_{L 1} & 0 & -1 & 0 \\
\theta_{L 2} & \theta_{K 2} & 0 & -1 \\
0 & \theta_{K 3} & 0 & \theta_{23} \\
0 & \theta_{K 4} & 0 & 0
\end{array}\right)\left(\begin{array}{c}
\widehat{W} \\
\hat{r} \\
\widehat{P_{1}} \\
\widehat{P_{2}}
\end{array}\right)=\left(\begin{array}{c}
0 \\
0 \\
0 \\
\alpha \theta_{K 4}
\end{array}\right)
$$

Similarly, if instead of capital-saving technological progress, Sector 4 undergoes capitalusing (i.e. skilled labour-saving) technological progress by $\alpha>0$, ceteris paribus, then we would have

$$
\left(\begin{array}{cccc}
\theta_{L 1} & 0 & -1 & 0 \\
\theta_{L 2} & \theta_{K 2} & 0 & -1 \\
0 & \theta_{K 3} & 0 & \theta_{23} \\
0 & \theta_{K 4} & 0 & 0
\end{array}\right)\left(\begin{array}{c}
\widehat{W} \\
\hat{r} \\
\widehat{P_{1}} \\
\widehat{P_{2}}
\end{array}\right)=\left(\begin{array}{c}
0 \\
0 \\
0 \\
\alpha \theta_{S 4}
\end{array}\right)
$$

Therefore, if Sector 4 undergoes capital-saving technological progress by $\alpha>0$, ceteris paribus, we get

$$
\begin{aligned}
& \hat{r}=\alpha>0 \\
& \hat{P}_{2}=-\alpha \theta_{K 3} / \theta_{23}<0 \\
& \widehat{W}=-\left[\alpha\left(\theta_{K 3}+\theta_{23} \theta_{K 2}\right) /\left(\theta_{23} \theta_{L 2}\right)\right]=-\left(\alpha \widetilde{\theta_{K 3}} / \theta_{23} \theta_{L 2}\right)<0
\end{aligned}
$$

Where $\widetilde{\theta_{K 3}}=\left(\theta_{K 3}+\theta_{23} \theta_{K 2}\right)=$ cost-share of direct and indirect capital usage by the vertically-integrated formal sector (Sector 3 ).

Similarly, if Sector 4 undergoes capital-using (i.e. skilled labour -saving) technological progress by $\alpha>0$, ceteris paribus,

$$
\begin{aligned}
& \hat{r}=\left(\alpha \theta_{S 4} / \theta_{K 4}\right)>0 \\
& \hat{P}_{2}=-\left(\alpha \theta_{K 3} \theta_{S 4} / \theta_{23} \theta_{K 4}\right)<0 \\
& \widehat{W}=-\left(\alpha \theta_{S 4} \widetilde{\theta_{K 3}} / \theta_{23} \theta_{L 2} \theta_{K 4}\right)<0
\end{aligned}
$$

Therefore, in either case, the endogenous price variables change in the same direction.

In case of capital-saving technological progress in Sector 4, ceteris paribus, by $\alpha>0$, we have 


$$
\widehat{a_{K 4}}=-\alpha \text {, with } \alpha>0 \text {, while } \widehat{a_{K 3}}=0
$$

Totally differentiating Equations (8) and (10), one can obtain

$$
\begin{aligned}
& \lambda_{S 3} \widehat{X_{3}}+\lambda_{S 4} \widehat{X_{4}}=-A \hat{r} \\
& \lambda_{K 3} \widehat{X_{3}}+\lambda_{K 4} \widehat{X_{4}}=\alpha \lambda_{K 4}+\hat{r}\left[B-r(\rho-1) K_{1}^{\prime}(\cdot) / \bar{K}\right]
\end{aligned}
$$

Where $A=\left(\lambda_{S 3} S_{S K}^{3}+\lambda_{S 4} S_{S K}^{4}\right)>0, B=\left(-\lambda_{K 3} S_{K K}^{3}-\lambda_{K 4} S_{K K}^{4}\right)>0, S_{j_{1} j_{2}}^{k}$ is the degree of substitution between factors $j_{1}$ and $j_{2}$ in the $k^{\text {th }}$ sector and $S_{j_{1} j_{2}}^{k}>0$ for $j_{1} \neq j_{2}$ and $<0$ for $j_{1}=j_{2}$. For example, $S_{S K}^{3}=\left(r / a_{S 3}\right)\left(\partial a_{S 3} / \partial r\right)>0, S_{K K}^{3}=\left(r / a_{K 3}\right)\left(\partial a_{K 3} / \partial r\right)<0$ and so on.

Solving Equations (A9)-(A10) simultaneously by Cramer's rule for $\widehat{X_{3}}$ and $\widehat{X_{4}}$ yields

$$
\begin{aligned}
& \widehat{X_{3}}=-\hat{r}\left[\lambda_{K 4}\left(A+\lambda_{S 4}\right)+\lambda_{S 4}\left\{B-r(\rho-1) K_{1}^{\prime}(\cdot) / \bar{K}\right\}\right] /|\lambda| \\
& \widehat{X_{4}}=\hat{r}\left[\lambda_{K 3}\left(A+\lambda_{S 4}\right)+\lambda_{S 3}\left\{B-r(\rho-1) K_{1}^{\prime}(.) / \bar{K}\right\}\right] /|\lambda|
\end{aligned}
$$

Since, Sector 4 is relatively capital-intensive vis-à-vis the vertically integrated formal sector in physical and value-sense, $|\lambda|=\left(\lambda_{S 3} \lambda_{K 4}-\lambda_{K 3} \lambda_{S 4}\right)>0$. Therefore, in case of a capitalsaving technological progress, if and only if $B \geq\left\{r(\rho-1) K_{1}^{\prime}(.) / \bar{K}\right\}$, and we should have $\widehat{X_{3}}<0$ and $\widehat{X_{4}}>0$.

Similarly, owing to the capital-using technological progress in Sector 4 by $\alpha>0$, ceteris paribus, we have

$$
\widehat{a_{S 4}}=-\alpha \text {, with } \alpha>0 \text {, while } \widehat{a_{S 3}}=0
$$

And total differentiation of Equations (8) and (10) yields

$$
\begin{aligned}
& \lambda_{S 3} \widehat{X_{3}}+\lambda_{S 4} \widehat{X_{4}}=\alpha \lambda_{S 4}-A \hat{r} \\
& \lambda_{K 3} \widehat{X_{3}}+\lambda_{K 4} \widehat{X_{4}}=\hat{r}\left[B-r(\rho-1) K_{1}^{\prime}(.) / \bar{K}\right]
\end{aligned}
$$

Solving Equations (A14)-(A15) simultaneously by Cramer's rule for $\widehat{X_{3}}$ and $\widehat{X_{4}}$ yields

$$
\widehat{X_{3}}=-\left[\lambda_{K 4}\left(A \hat{r}-\alpha \lambda_{S 4}\right)+\hat{r} \lambda_{S 4}\left\{B-r(\rho-1) K_{1}^{\prime}(.) / \bar{K}\right\}\right] /|\lambda|
$$




$$
\widehat{X_{4}}=\left[\lambda_{K 3}\left(A \hat{r}-\alpha \lambda_{S 4}\right)+\hat{r} \lambda_{S 3}\left\{B-r(\rho-1) K_{1}^{\prime}(.) / \bar{K}\right\}\right] /|\lambda|
$$

Hence, $\widehat{X}_{3}<0$ and $\widehat{X_{4}}>0$ if and only if $\hat{r} \geq\left(\alpha \lambda_{S 4} / A\right)$ and $B \geq\left\{r(\rho-1) K_{1}^{\prime}(.) / \bar{K}\right\}$ hold; with at least one having a strict inequality.

It is also straightforward from Equation (11) that $\widehat{X_{3}}=\widehat{X_{2}}$ since $\lambda_{23}=\frac{a_{23} X_{3}}{X_{2}}=1$. Therefore, Sector 2 also contracts. Now totally differentiating Equation (9) and substituting $\widehat{X_{2}}=\widehat{X_{3}}$ from Equation (A16); it is straightforward show that $\widehat{X}_{1}>0$ when $\widehat{X_{2}}<0$. Hence, we have our Proposition 1.

\section{Proof of Proposition 2}

In Sector 3, the technological improvement takes place through the uniform reduction of the ad valorem rate of tariff $(t)$ imposed on the imports of the array of intermediate inputs, $M$, from abroad, ceteris paribus.

$$
\left(\begin{array}{cccc}
\theta_{L 1} & 0 & -1 & 0 \\
\theta_{L 2} & \theta_{K 2} & 0 & -1 \\
0 & \theta_{K 3} & 0 & \theta_{23} \\
0 & \theta_{K 4} & 0 & 0
\end{array}\right)\left(\begin{array}{c}
\widehat{W} \\
\hat{r} \\
\widehat{P_{1}} \\
\widehat{P_{2}}
\end{array}\right)=\left(\begin{array}{c}
0 \\
0 \\
\Omega \\
0
\end{array}\right)
$$

Where $\Omega=-\hat{t}\left[\left(\frac{t}{1+t}\right) \theta_{M 3}+t\left(\frac{W_{S}^{*}}{P_{3}^{*}}\right)\left(\frac{\partial a_{S 3}}{\partial A}\right) A^{\prime}\right]>0$, when $d t<0$.

Solving Equation (A18) by Cramer’s rule we get

$$
\begin{aligned}
& \hat{r}=0 \\
& \widehat{P_{2}}=\left(\Omega / \theta_{23}\right)>0 \\
& \widehat{W}=\left(\Omega / \theta_{23} \theta_{L 2}\right)>0
\end{aligned}
$$

Thus, informal wage will unambiguously increase.

Since $r$ and hence $R$ are not changing given $\rho$, there is also no change in credit allocation among the two domestic credit markets. Therefore, we have

$\widehat{a_{S 3}}=\widehat{a_{K 3}}=\widehat{a_{S 4}}=\widehat{a_{K 4}}=0$, and owing to fixed-coefficient production technologies in sectors 1 and $2, \widehat{a_{L 1}}=\widehat{a_{L 2}}=\widehat{a_{K 2}}=0$. 
Therefore, total differentiation of Equations (8) and (10) now yields respectively

$$
\begin{aligned}
& \lambda_{S 3} \widehat{X_{3}}+\lambda_{S 4} \widehat{X_{4}}=-\left(\frac{t X_{3}}{\bar{S}}\left(\frac{\partial a_{S 3}}{\partial A}\right) A^{\prime}\right) \hat{t}=\Phi>0 \\
& \lambda_{K 3} \widehat{X_{3}}+\lambda_{K 4} \widehat{X_{4}}=0
\end{aligned}
$$

It is straightforward to obtain by solving Equations (A23) and (A24) simultaneously that $\widehat{X_{3}}=\left\{\Phi \lambda_{K 4} /\left(\lambda_{S 3} \lambda_{K 4}-\lambda_{K 3} \lambda_{S 4}\right)\right\}>0$

And,

$\widehat{X_{4}}=-\left\{\Phi \lambda_{K 3} /\left(\lambda_{S 3} \lambda_{K 4}-\lambda_{K 3} \lambda_{S 4}\right)\right\}<0$.

Since, sector 3 is more skilled-labour intensive with respect to capital in the HO-nugget.

Therefore, $\widehat{X_{2}}=\widehat{X_{3}}>0$ and $\widehat{X_{1}}<0$.

This is precisely what has been argued in Proposition 2.

\section{Appendix - II}

\section{Derivation of TFPG:}

First we have derived net value added (net VA) = gross value added - value addition by intermediate inputs - depreciation. Then we deflated this variable using WPI for 2001-02 base year. The TFPG = growth rate of net VA - weighted growth rates of capital and labour (when the weights are share of the factors in net value-added). So Divisia-Tornquist (D-T) approximation has been used for the calculation of TFPG. The TFPG under the D-T approximation is given by the following equation:

$$
\begin{aligned}
T F P G= & \left(\ln Q_{t}-\ln Q_{t-1}\right)-\frac{1}{2}\left[\left(s_{L, t}-s_{L, t-1}\right)\left(\ln L_{t}-\ln L_{t-1}\right)+\left(s_{K, t}-s_{K, t-1}\right)\left(\ln K_{t}-\right.\right. \\
& \left.\left.\ln K_{t-1}\right)\right]
\end{aligned}
$$

Where $\mathrm{Q}=$ net $\mathrm{VA}, s_{L}=$ share of labour in net $\mathrm{VA} ; s_{K}=$ share of capital in net VA. We consider the share of emoluments in net value added as $s_{L}$. Assuming CRS, $s_{K}=1-s_{L}$. 


\section{Data Description and Construction of Variables:}

The informal sector real wages have been constructed by deflating the nominal wages in the urban NDMEs using 2001-02 Consumer Price Indices (CPI). And the informal real fixed assets (proxy for capital accumulation in the informal sector) have been formed by deflating the nominal figures using 2001-02 Wholesale Price Indices (WPI) for Machinery and Machine Products.

We have constructed the variable (termed as 'Linkage') capturing formal sector subcontracting activities as 'total inputs' minus 'fuel consumed' in the ASI survey data. Subsequently, this variable was deflated using 2001-02 WPI for Manufactured products.

All the price indices (CPI, WPI for Manufactured products and WPI for Machinery and Machine products) were available at the national level, thus price differences between states were adjusted using the ratio of state to national GDP deflator.

\section{Appendix - III}

Table A1: Descriptive Statistics

\begin{tabular}{|c|c|c|c|c|c|}
\hline Variable & Observations & Mean & Standard Deviation & Minimum & Maximum \\
\hline Informal Wage 1989 & 27 & 90.10185 & 37.58973 & 47.32 & 180.01 \\
\hline Fixed Assets 1989 & 27 & 775.9122 & 441.5575 & 298.34 & 1937.68 \\
\hline Linkage 1989 & 27 & 15927.22 & 21047 & 1.93 & 92680.77 \\
\hline Informal Wage 1994 & 27 & 151.2089 & 35.65809 & 96.69 & 211.79 \\
\hline Fixed Assets 1994 & 27 & 441.3022 & 559.9268 & 46.83 & 2874.97 \\
\hline Linkage 1994 & 27 & 21081.6 & 28079.55 & 16.17 & 120840.9 \\
\hline Informal Wage 2000 & 27 & 197.2741 & 37.49708 & 117.8 & 264.97 \\
\hline Fixed Assets 2000 & 27 & 2617.223 & 2267.978 & 810.1 & 12748.86 \\
\hline Linkage 2000 & 27 & 25532.24 & 35163.41 & 14.84 & 144254.9 \\
\hline Informal Wage 2005 & 27 & 194.5222 & 52.57534 & 94.78 & 321.53 \\
\hline Fixed Assets 2005 & 27 & 2827.415 & 1623.554 & 1079.22 & 7698.67 \\
\hline Linkage 2005 & 27 & 43442.49 & 60077.58 & 25.11 & 236271.8 \\
\hline Informal Wage 2010 & 27 & 269.1952 & 75.94624 & 153.08 & 438.77 \\
\hline Fixed Assets 2010 & 27 & 12006.97 & 12035 & 1593.86 & 56504.33 \\
\hline Linkage 2010 & 27 & 66629.96 & 97603.66 & 79.41 & 372947.4 \\
\hline
\end{tabular}




\section{References}

Abraham, V. 2010. The effect of information technology on wage inequality: evidence from Indian manufacturing sector. CDS working papers no. 437, Trivandrum, CDS.

Agenor, P.R. 1996. The Labor Market and Economic Adjustment. IMF Staff Papers no. 32, pp. $261-335$.

Beladi, H., Chaudhuri, S. and Yabuuchi, S. 2008. 'Can International Factor Mobility Reduce Wage Inequality in a Dual Economy?' Review of International Economics, Vol. 16, pp. 893 - 903.

Beladi, H., Vina, L. De la and Marjit, S. 2012. 'Technological Progress with Segmented Labor Markets.' Review of Development Economics, Vol. 16, pp. 148 - 152. doi: 10.1111/j.1467-9361.2011.00651.x.

Berman, E., Somanathan, R. and Tan, H.W. 2005. Is Skill-biased Technological Change Here Yet? Evidence from Indian Manufacturing in the 1990s. World Bank Policy Research Working Paper 3761.

Chaudhuri, S. 2003. 'How and how far to liberalize a developing country with informal sector and factor market distortions.' Journal of International Trade and Economic Development, Vol. 12, No. 4, pp. 403-428.

Chaudhuri, S. and Mukhopadhyay, U. 2010. Revisiting the Informal Sector: A General Equilibrium Approach. New York: Springer.

Ethier, Wilfred J. 2005. 'Globalization, globalisation: Trade, technology, and wages.' International Review of Economics \& Finance, Vol. 14, No. 3, pp. 237-258.

Findlay, R. 1978. 'Relative Backwardness, Direct Foreign Investment and the Transfer of Technology: a Simple Dynamic Model.' Quarterly Journal of Economics 92, pp. 1-16.

Findlay, Ronald and Jones, Ronald W. 2000. 'Factor Bias and Technical Progress.' Economics Letters, Vol. 68, pp. $303-308$.

Goldberg, P and Pavcnik, N. 2003. 'The Response of the Informal Sector to Trade Liberalisation.’ Journal of Development Economics, Vol. 72, No. 2, pp. 463-496.

Goldar, B. and Kumari, A. 2003. 'Import Liberalization and Productivity Growth in Indian Manufacturing Industries in the 1990s.' The Developing Economies, Vol. 41, pp. 436-60.

Guha-Khasnobis, B. and Bari, F. 2003. 'Sources of Growth in South Asian Countries,' in: Ahluwalia, I. J. and Williamson, J. (eds.) The South Asian Experience with Growth, Oxford University Press. 
Gupta, M. R. 1994. 'Duty-Free Zone, Unemployment and Welfare: a Note', Journal of Economics, Vol. 59, pp. 217-236.

Hasan, R. 2002. 'The impact of imported and domestic technologies on the productivity of firms: panel data evidence from Indian manufacturing firms.' Journal of Development Economics, Vol. 69, pp. 23-49.

Hulten, C.R. and Srinivasan, S. 1999. Indian Manufacturing Industry: Elephant or Tiger? New Evidence on the Asian Miracle. National Bureau of Economic Research Working Paper Series, No. 7441.

Jackelen, H.R. and Rhyne, E. 1991. 'Towards a More Market-oriented Approach to Credit and Savings for the Poor.' Small Enterprise Development Vol. 2, pp. 4-20.

Jhavbala, R. and Subrahmanya, R. K. A 2000. 'The Unorganised Sector: Work Security and Social Protection'. Sage Publications: New Delhi.

Jones, R.W. 1965. 'The Structure of Simple General Equilibrium Models.' Journal of Political Economy, Vol. 73, No. 6, pp. 551 - 572.

Jones, R.W. 1971. 'A Three-factor Model in Theory, Trade and History' in: Bhagwati, J. et al. (eds.), Trade, Balance of Payments and Growth. North-Holland: Amsterdam.

Jones, R.W. 1996. 'International Trade, Real Wages and Technical Progress: The Specificfactors Model.' International Review of Economics and Finance 5, pp. 113 - 124.

Jones, R.W. 2003. 'Joint Outputs and Real Wage Rates.' International Review of Economics and Finance, Vol. 12, pp. 513 - 516.

Jones, R.W. 2006. 'Protection and Real Wages: The History of an Idea.' Japanese Economic Review, Vol. 57, pp. 457 - 466.

Kar, S., Marjit, S. and Sarkar, P. 2003. Trade reform, internal capital mobility and informal wage: Theory and evidence. WIDER Conference on Sharing Global Prosperity, Helsinki.

Kar, S. and Marjit, S. 2009. 'Urban Informal Sector and Poverty.' International Review of Economics and Finance, Vol. 18, pp. 631-642.

Krugman, P.R. 2000. 'Technology, trade and factor prices.' Journal of International Economics, Vol. 50, pp. $51-71$.

Maldonado, C. and Sethuraman, S. V. 1992. Technological capability in the Informal sector: Metal manufacturing in developing countries, International Labour Organisation.

Marjit, S. 2003. 'Economic Reform and Informal Wage: General Equilibrium Analysis.' Journal of Development Economics, Vol. 72, No. 1, pp. 371-8.

Marjit, S. and Kar, S. 2004. 'Pro-Market Reform and Informal Wage: Theory and the Contemporary Indian Perspective.’ India Macroeconomics Annual 2004-05, pp. 130-156.

Marjit, S., Kar, S. and Beladi, H. 2007a. 'Trade Reform and Informal Wages.' Review of Development Economics, Vol. 11, No. 2, pp. 313-320. 
Marjit, S., Kar, S. and Acharyya, R. 2007b. 'Agricultural prospects and informal wage in general equilibrium.’ Economic Modelling, Vol. 24, pp. 380-385.

Marjit, S., and Kar, S. 2008a. 'Labor Productivity Growth, Informal Wage and Capital Mobility - A General Equilibrium Analysis.' In: Kanbur, R. and Svejnar, J. (eds.) Labour Markets and Economic Development, NY: Routledge, 2008.

Marjit, S., and Kar, S. 2008b. 'Productivity and Wage in the Informal Sector' in: Footprints of Development and Change, Chapter 5 (V.K.R.V. Rao Centenary Volume), AF: New Delhi.

Marjit, S., Kar, S. and Maity, D. 2008. 'Labour Market Reform and Poverty - The Role of Informal Sector.' In: Bhaskar Dutta (ed.) Issues in Development, World Scientific Press: New York.

Marjit, S., and Kar, S. 2009. 'A Contemporary Perspective on the Informal Labour Market: Theory, Policy and the Indian Experience.' Economic and Political Weekly, Vol. XLIV, No. 14, pp. $60-71$.

Marjit, S., Kar, S. and Chaudhuri, S. 2011. 'Recession in the skilled sector and implications for informal wage.’ Research in Economics, Vol. 65, pp. 158-163.

Mukherjee, S. 2012. 'Revisiting the Apparent Paradox: Foreign Capital Inflow, Welfare Amelioration and 'Jobless Growth' with Agricultural Dualism and Non-traded Intermediate Input.’ Journal of Economic Integration, Vol. 27, No. 1, pp. 123-133.

Mukherjee, S. 2014. 'Liberalisation and 'Jobless Growth' in Developing Economy - Some Extended Results,' Journal of Economic Integration Vol. 29, No. 3, pp. 450-469.

National Sample Survey Organization of India (NSSO) 1989-2010. Survey of Unorganized Manufacturing Sector in India, Department of Statistics and Programme Implementation, Government of India — various issues.

Papola, T. S. 1981. Urban informal sector in a developing economy, Vikas Publishing House: New Delhi.

Pattnayak, S.S. and Thangavelu, S.M. 2005. 'Economic reform and productivity growth in Indian manufacturing industries: an interaction of technical change and scale economies.' Economic Modelling, 22, 601-615.

Planning Commission, Government of India (2007-2014). Report of the Expert Group to Review the Methodology for Measurement of Poverty.

Ramaswami, K.V. 1999. 'The Search for Flexibility in Indian Manufacturing: New Evidence on Outsourcing Activities.' Economic and Political Weekly Vol. 34, No. 6, pp. 363-368.

Romatet, E. 1983. 'Calcutta's Informal Sector: Theory and Reality.' Economic and Political Weekly, Vol. 18, pp. 2115-2128.

Sanyal, K.K. and Jones, R. W. 1982. 'The theory of trade in middle products.' The American Economic Review, Vol. 72, pp. 16-31. 
Schneider, F. and Enste, D.H. 2000. 'Shadow Economies: Size, Causes, and Consequences.' Journal of Economic Literature, Vol. 38, pp. 77 - 114.

Seker, M., and Rodriguez-Delgado, J. D. 2011. Imported Intermediate Goods and Product Innovation: Evidence from India. Mimeo.

Sethuraman, S. 1984. 'The urban informal sector in developing countries: Employment, poverty and environment' in: The urban informal sector in developing countries: Employment, poverty and environment. International Labour Organisation.

Sundaram, A., Ahsan, R. N., and Mitra, D. 2012. 'Complementarity between Formal and Informal Manufacturing in India.' In Bhagwati, J. and Panagariya, A. (eds.) Reforms and Economic Transformation in India, Oxford University Press: NY.

Topalova, P. and Khandelwal, A. 2010. 'Trade Liberalization and Firm Productivity: The Case of India.' Review of Economics and Statistics, Vol. 93, pp. 995-1009. 